\title{
Enterococcus canintestini sp. nov., from faecal samples of healthy dogs
}

Correspondence

Sabri M. Naser

Sabri.Naser@Ugent.be

\author{
Sabri M. Naser, ${ }^{1,2}$ Marc Vancanneyt, ${ }^{2}$ Evelyne De Graef, ${ }^{3}$ Luc A. Devriese, ${ }^{3}$ \\ Cindy Snauwaert, ${ }^{2}$ Karen Lefebvre, ${ }^{2}$ Bart Hoste, ${ }^{2}$ Pavel Švec, ${ }^{4}$ \\ Annemie Decostere, ${ }^{3}$ Freddy Haesebrouck ${ }^{3}$ and Jean Swings ${ }^{1,2}$ \\ 1,2Laboratory of Microbiology ${ }^{1}$ and BCCM/LMG ${ }^{\mathrm{TM}}$ Bacteria Collection², Ghent University, \\ K. L. Ledeganckstraat 35, Ghent 9000, Belgium \\ ${ }^{3}$ Department of Pathology, Bacteriology and Poultry Diseases, Faculty of Veterinary Medicine, \\ Ghent University, Salisburylaan 133, B-9820 Merelbeke, Belgium \\ ${ }^{4}$ Czech Collection of Microorganisms, Faculty of Science, Masaryk University, Tvrdého 14, \\ 60200 Brno, Czech Republic
}

\begin{abstract}
The taxonomic position of strain LMG $13590^{\top}$, originally isolated from dog faeces and classified as Enterococcus dispar in the BCCM/LMG Bacteria Catalogue, was reinvestigated. This strain and 12 recent isolates from faecal samples of healthy dogs occupied a clearly separate position when investigated with multilocus sequence analysis (MLSA) of the genes encoding the alpha subunit of ATP synthase (atpA), RNA polymerase alpha subunit $(r p o A)$ and phenylalanyl-tRNA synthase alpha subunit (pheS). The $16 \mathrm{~S}$ rRNA gene sequence of one representative strain showed highest similarities of 98-99\% with E. dispar LMG $13521^{\top}$, Enterococcus canis LMG $12316^{\top}$ and Enterococcus asini LMG $18727^{\top}$. A further polyphasic taxonomic study based on whole-cell protein fingerprinting, DNA-DNA hybridization and biochemical features demonstrated that the 13 enterococcal dog faecal strains represent a single, novel Enterococcus species for which the name Enterococcus canintestini sp. nov. is proposed. The type strain is LMG $13590^{\top}$ $\left(=\mathrm{CCM} 7285^{\top}\right)$.
\end{abstract}

The genus Enterococcus currently comprises 30 species. Enterococci are natural inhabitants of the mammalian gastrointestinal tract (Devriese et al., 1992; Klein, 2003). However, enterococci are ubiquitous and can be found freeliving in soil, on plants or in dairy products (Baele et al., 2000; Devriese et al., 1995; Franz et al., 1999). Enterococcus dispar was originally described by Collins et al. (1991) on the basis of two strains from human clinical sources, one from synovial fluid (LMG $13521^{\mathrm{T}}$ ) and one from a stool culture. In 1993, an additional strain, LMG 13590, isolated from the faeces of a dog, was assigned to the species based on similar characteristics. A recent biodiversity study of the intestinal flora of dogs revealed that one enterococcal taxon was

Published online ahead of print on 27 May 2005 as DOI 10.1099/ ijs.0.63752-0.

Abbreviations: $L A B$, lactic acid bacteria; MLSA, multilocus sequence analysis.

The GenBank/EMBL/DDBJ accession number for the 16S rRNA gene sequence of LMG $13590^{\top}$ is AJ888906.

A distance matrix tree showing the phylogenetic relationships of $E$. canintestini sp. nov. and other enterococcal reference species based on $16 \mathrm{~S}$ rRNA gene sequence comparisons is available as supplementary material in IJSEM Online. commonly occurring in dog faeces. These isolates were biochemically most similar to E. dispar but differed in a number of tests which were considered typical for the species (De Graef et al., 2005). In the present study, the taxonomic relationships between $E$. dispar strains and the novel dog faecal isolates were investigated.

Two culture collection strains, E. dispar LMG $13521^{\mathrm{T}}$ and LMG 13590, and the following 12 isolates from faecal samples of healthy dogs from different owners distributed over Flanders were included in the study: LMG 22752 (eve 16a), LMG 22753 (eve 21a), LMG 22754 (eve 117b), LMG 22755 (eve 115a), LMG 22976 (eve 2b), LMG 22977 (eve 3b), LMG 22978 (eve 10a), LMG 22979 (eve 15b), LMG 22980 (eve 19c), LMG 22981 (eve 23b), LMG 22982 (eve 109c) and LMG 22983 (eve 125a). Cultivation and maintenance conditions for the isolates and reference strains were MRS agar (Oxoid) and incubation at $30^{\circ} \mathrm{C}$ for $24 \mathrm{~h}$, unless indicated otherwise.

Initially the two culture collection strains, E. dispar LMG $13521^{\mathrm{T}}$ and LMG 13590, were included in a multilocus sequence analysis (MLSA) study applied for the reliable identification of all currently described enterococcal species. MLSA compares the primary DNA sequences from multiple 
conserved protein-coding loci to assess the diversity and relationships of different isolates across related taxa, thereby using an appropriate phylogenetic or cladistic approach. The criteria used for selecting the multiple protein-coding loci (housekeeping genes) are: (i) widely distributed among lactic acid bacterial (LAB) whole genome sequences; (ii) present in only one copy per organism; and (iii) mutually unlinked in location. Partial sequences for the genes encoding the alpha subunit of ATP synthase (atpA), RNA polymerase alpha subunit ( $r p o A)$ and phenylalanyl-tRNA synthase alpha subunit (pheS) were determined. Amplification and sequencing reactions were performed as described by Naser et al. (2005a, b). The designed primers enabled the amplification and final comparison of atpA (1102 bp), rpoA (533 bp) and pheS (455 bp) fragments of all Enterococcus species. The simultaneous use of several housekeeping genes in bacterial taxonomy gives higher taxonomic resolution between Enterococcus species and allows the discrimination of all currently recognized species of Enterococcus to a greater degree than the use of $16 \mathrm{~S}$ rRNA gene sequences. The MLSA scheme is best suited for analysis at the species and genus levels as it integrates the information from different molecular markers from the bacterial chromosome (Stackebrandt et al., 2002; Zeigler, 2003). At the interspecies level, all enterococcal species were clearly differentiated on the basis of atpA, rpoA and pheS gene sequences, with a maximum of 92,97 and $86 \%$ similarity, respectively (Naser et al., 2005a, b). Evaluation of the intraspecies variation showed that atpA, rpoA and pheS genes had a high degree of homogeneity among strains of the same species. The MLSA approach for the analysis of the genus Enterococcus provides a reliable, highly reproducible, low-cost and rapid identification tool for the currently known species.

Neighbour-joining trees of the housekeeping genes investigated showed that strain LMG 13590 represents a separate (a) $\operatorname{atp} A$

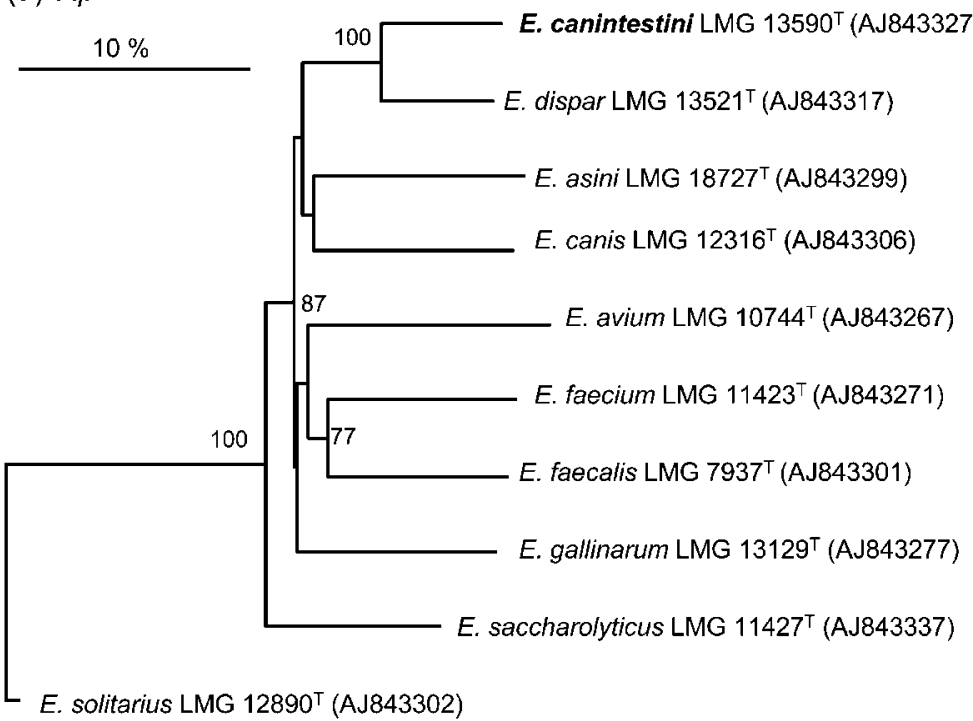

(b) $r p o A$

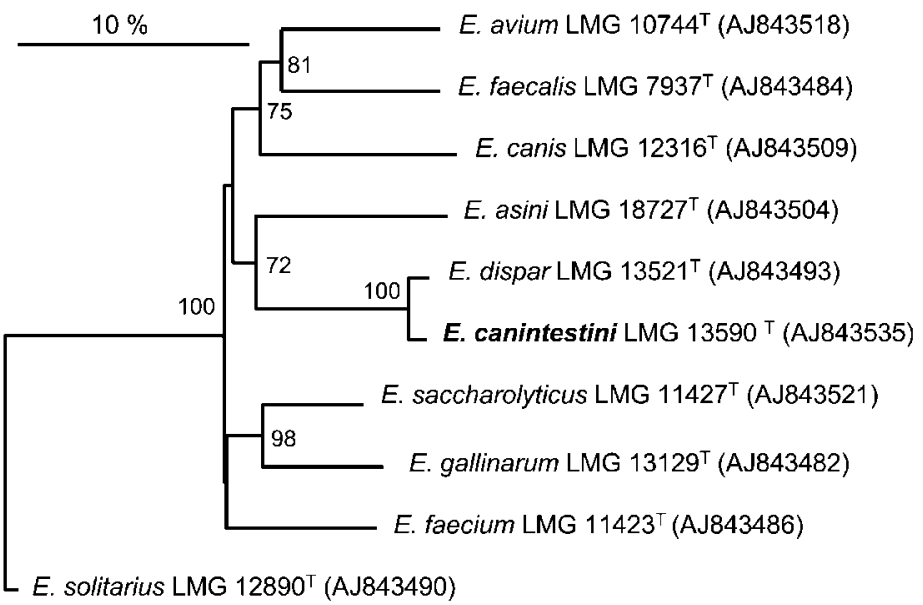

Fig. 1. Neighbour-joining trees showing the relationships of $E$. canintestini sp. nov. and other enterococcal reference species based on $\operatorname{atp} A(\mathrm{a})$ and $r p o A(\mathrm{~b})$ sequence comparisons. E. solitarius LMG $12890^{\top}$ was used as the outgroup. Bootstrap percentages $(\geqslant 50)$ after 500 simulations are shown. Bar, $10 \%$ sequence divergence. 
lineage distantly related to the other enterococcal species and to E. dispar LMG $13521^{\mathrm{T}}$ (90, 98 and $89 \%$ atpA, rpoA and pheS gene sequence similarities, respectively). The other closest type strains were Enterococcus asini LMG $18727^{\mathrm{T}}(83$ and $84 \%$ atpA and rpoA gene sequence similarities, respectively), Enterococcus canis LMG $12316^{\mathrm{T}}$ (83\% atpA and rpoA gene sequence similarities, respectively) and Enterococcus saccharolyticus LMG $11427^{\mathrm{T}}$ (83, 84 and $84 \%$ atpA, $r p o A$ and pheS gene sequence similarities, respectively) (Figs 1 and 2 ). In a further study, the pheS gene sequences of the 12 isolates from dog faeces were determined and, together with strain LMG 13590, they occupied a homogeneous and separate position in the pheS tree $(98.6 \%$ pheS gene sequence similarity) (Fig. 2).

The phylogenetic position of strain LMG 13590 was determined by complete $16 \mathrm{~S}$ rRNA gene sequence analysis. Genomic DNA was prepared according to the protocol of Niemann et al. (1997). 16S rRNA gene amplification, purification and sequencing was performed as described by Vancanneyt et al. (2004) with the following modifications: PCR-amplified 16S rRNA genes were purified by using a

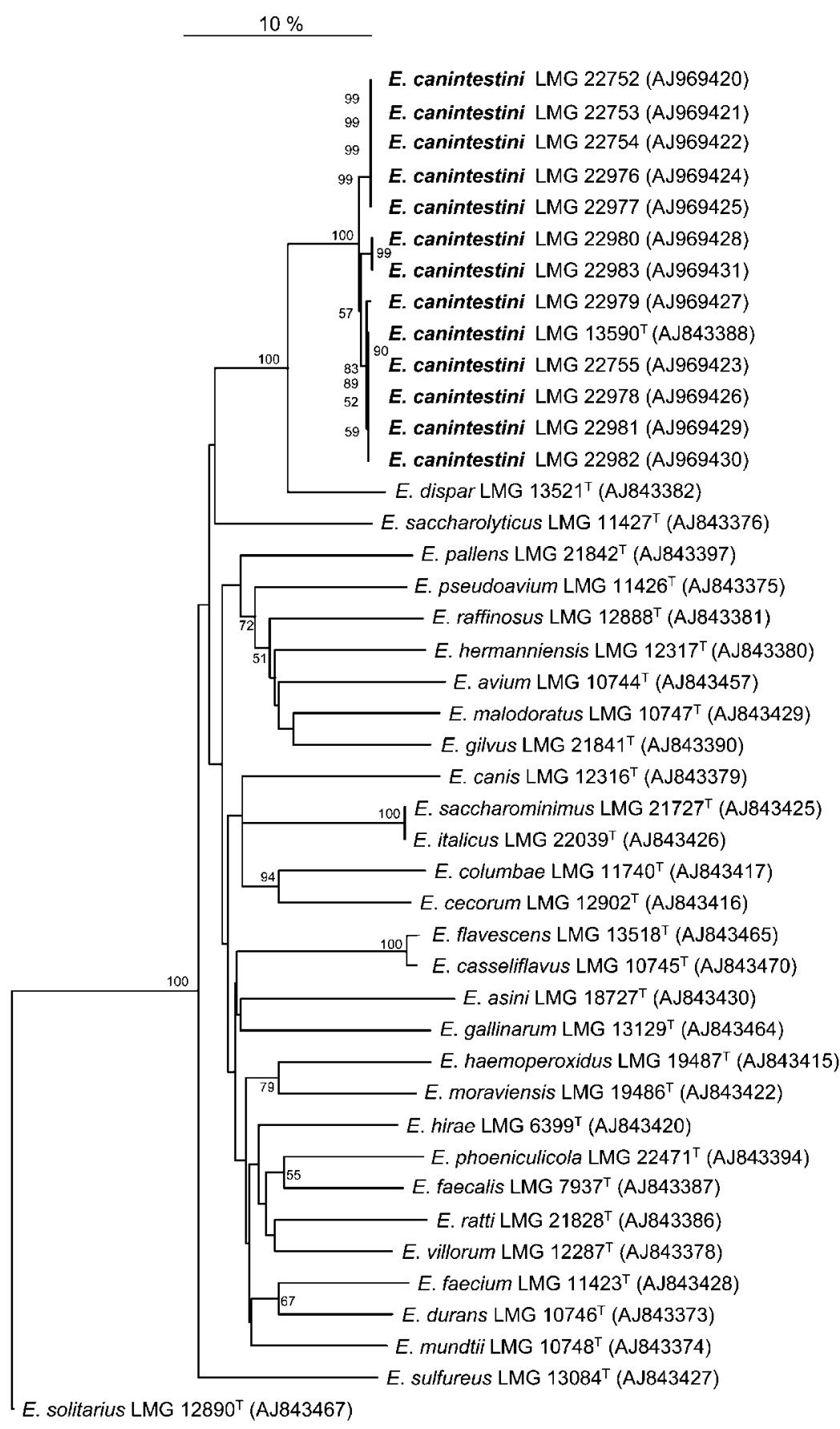

Fig. 2. Neighbour-joining tree showing the relationships of $13 \mathrm{E}$. canintestini sp. nov. strains and other enterococcal reference species based on pheS sequence comparisons. E. solitarius LMG $12890^{\top}$ was used as the outgroup. Bootstrap percentages $(\geqslant 50)$ after 500 simulations are shown. Bar, $10 \%$ sequence divergence. 
NucleoFast 96 PCR clean-up kit (Macherey-Nagel). Sequencing reactions were performed with a BigDye terminator cycle sequencing kit (Applied Biosystems) and purified by using a Montage $\mathrm{SEQ}_{96}$ sequencing reaction clean-up kit (Millipore). Sequencing was performed with an ABI Prism 3100 Genetic Analyzer (Applied Biosystems). Sequence assembly was done by using the GENEBUILDER program (Applied Maths). The 16S rRNA gene sequences of strain LMG 13590 and those of strains retrieved from GenBank/EMBL were aligned and a phylogenetic tree was constructed from the global alignment by using the neighbour-joining method using the BioNumerics software package, version 3.50 (Applied Maths). Bootstrap analysis was undertaken to test the statistical reliability of the topology of the neighbour-joining tree using 500 bootstrap resamplings of the data (Supplementary Fig. S1 available in IJSEM Online). The strain was classified in the genus Enterococcus with E. dispar LMG $13521^{\mathrm{T}}$, E. asini LMG $18727^{\mathrm{T}}$ and E. canis LMG $12316^{\mathrm{T}}$ as the nearest neighbours (99, 98 and $98 \% 16 \mathrm{~S}$ rRNA gene sequence similarities, respectively).

E. dispar LMG $13521^{\mathrm{T}}$, E. canis $12316^{\mathrm{T}}$, E. asini LMG $18727^{\mathrm{T}}$, strain LMG 13590 and the 12 dog faecal isolates were investigated using PAGE of whole-cell proteins. Whole-cell protein extracts were prepared and SDS-PAGE was performed as described by Pot et al. (1994). Densitometric analysis, normalization and interpolation of protein profiles and numerical analysis were performed by using the GelCompar software package, versions 3.1 and 4.0, respectively (Applied Maths). The 12 dog strains and LMG
13590 constituted a homogeneous and separate cluster (Fig. 3).

After extraction of genomic DNA as described by Baele et al. (2000), the 12 strains isolated from dog faecal samples, were subjected to tRNA intergenic length polymorphism analysis (tDNA-PCR). PCR was carried out using the tRNA-gene consensus primers $\mathrm{T} 5 \mathrm{~A}$ and fluorescently labelled T3B (Welsh \& McClelland, 1991), which are directed outwardly against the conserved edges of the tRNA genes. PCR mixtures and cycle conditions were as described previously (Baele et al., 2000). Capillary electrophoresis of the DNA fragments was performed with an ABI Prism 310 Genetic Analyzer (Applied Biosystems). Electrophoretograms obtained with GENESCAN software were compared with a database developed at the Faculty of Veterinary Medicine, Ghent University, using a software program developed at our laboratory (Baele et al., 2000). The pattern of the $12 \mathrm{dog}$ isolates was composed of mean peak positions at $56 \cdot 9,62 \cdot 6,64 \cdot 4,79 \cdot 4,157,230 \cdot 1,249 \cdot 5$ and $265.5 \mathrm{bp}$, which corresponded to the peak values of LMG 13590 included in our database as one of the E. dispar reference strains. A comparison of this pattern with the fragment lengths of all known LAB species in our database, including E. dispar type strain LMG $13521^{\mathrm{T}}$, revealed a separate grouping for the 12 dog faecal isolates and LMG 13590.

DNA G + C content was determined for E. dispar LMG $13521^{\mathrm{T}}$ and three dog faecal isolates, LMG 13590, LMG 22752 and LMG 22753. Cells were cultivated in MRS broth at $37^{\circ} \mathrm{C}$ for $24 \mathrm{~h}$. DNA was extracted from $0 \cdot 5-0 \cdot 75 \mathrm{~g}$ (wet

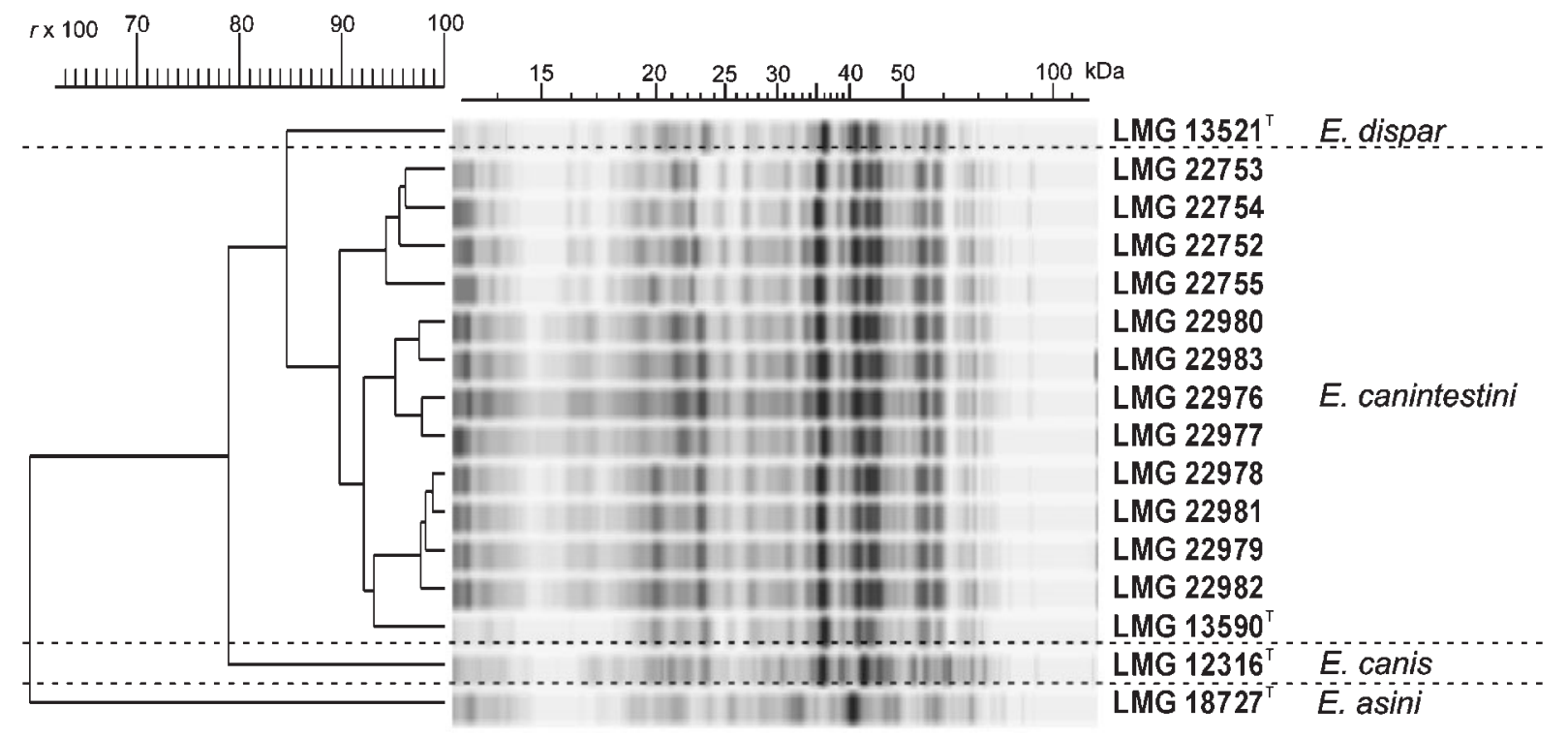

Fig. 3. Protein profiles and corresponding dendrogram derived from the unweighted pair group mean linkage of correlation coefficients $r$ (expressed for convenience as a percentage value) of E. canintestini sp. nov. strains and some related reference species. 
weight) using the protocol described by Marmur (1961) with the following modifications: (i) cells were suspended overnight in Tris/ $\mathrm{HCl}$ buffer that contained lysozyme $\left(8 \mathrm{mg} \mathrm{ml}^{-1}\right)$ before the addition of SDS and (ii) lysed cells were treated with proteinase $\mathrm{K}\left(360 \mathrm{mg} \mathrm{l}^{-1}\right.$; Merck) at $37^{\circ} \mathrm{C}$ for $2 \mathrm{~h}$. For determination of the DNA G $+\mathrm{C}$ content, DNA was degraded enzymically into nucleosides as described by Mesbah et al. (1989). The nucleoside mixture was then separated by HPLC using a Waters SymmetryShield C8 column maintained at a temperature of $37^{\circ} \mathrm{C}$. The solvent was $0.02 \mathrm{M} \mathrm{NH} \mathrm{NH}_{2} \mathrm{PO}_{4}(\mathrm{pH} 4.0)$ with $1.5 \%$ acetonitrile. Non-methylated lambda-phage DNA (Sigma) was used as the calibration reference. The DNA G+C content of the dog faecal strains was in a range from 36 to $37 \mathrm{~mol} \%$. For E. dispar LMG $13521^{\mathrm{T}}$, a slightly higher value of $38 \mathrm{~mol} \%$ was observed.

DNA-DNA hybridizations were performed between strains E. dispar LMG $13521^{\mathrm{T}}$ and LMG 13590, LMG 22752 and LMG 22753. Genomic DNA was prepared according to the protocol of Niemann et al. (1997). The microplate method was used as described by Ezaki et al. (1989) and Goris et al. (1998), using an HTS7000 Bio Assay Reader (Perkin Elmer) for the fluorescence measurements. Biotinylated DNA was hybridized with unlabelled single-stranded DNA, which was bound non-covalently to microplate wells. Hybridizations were performed at $36^{\circ} \mathrm{C}$ with the hybridization mixture $(2 \times$ SSC, $5 \times$ Denhardt's solution, $2.5 \%$ dextran sulfate, $50 \%$ formamide, $100 \mu \mathrm{g}$ denatured salmon sperm DNA $\mathrm{ml}^{-1}, 1250 \mathrm{ng}$ biotinylated probe DNA $\mathrm{ml}^{-1}$ ). The DNADNA relatedness percentages presented are means based on at least two independent hybridization experiments. Reciprocal reactions were performed and also considered as independent hybridization experiments. Hybridization values of $51.5 \%$ were found with the type strain of E. dispar. Hybridization values of $93-96 \%$ were found between LMG 13590, LMG 22752 and LMG 22753, indicating that these three dog faecal strains constitute a single novel species.

Growth tests were carried out as described by Švec et al. (2001). Lancefield antigens were detected by using a Streptococcal grouping kit (Oxoid). Biochemical reactions were determined in API $50 \mathrm{CH}$ galleries under paraffin cover and in the API 20 STREP system (bioMérieux). The unknown dog faecal isolates present a number of characteristics in common with their closest phylogenetic relative, E. dispar, but, as outlined in Table 1, several phenotypic differences were noted compared with the $E$. dispar species description. These differences can easily be used to differentiate the unidentified dog faecal isolates from this related enterococcal species.

The overall results of the present study allowed us to assign 13 strains, LMG $13590^{\mathrm{T}}$, LMG 22752, LMG 22753, LMG 22754, LMG 22755, LMG 22976, LMG 22977, LMG 22978, LMG 22979, LMG 22980, LMG 22981, LMG 22982 and LMG 22983, to a novel species for which we propose the name Enterococcus canintestini sp. nov.
Table 1. Characteristics that differentiate $E$. canintestini sp. nov. and E. dispar

The data for E. dispar are as described by Collins et al. (1991) based on two strains, E18- $1^{\mathrm{T}}$ and $174-85$. For the E. canintestini strains, values shown are for the number of strains showing a positive reaction out of the number of strains tested. +, Positive; $\mathrm{v}$, variable.

\begin{tabular}{|lcc|}
\hline Characteristic & E. dispar & $\begin{array}{c}\text { E. canintestini } \\
\text { sp. nov. }\end{array}$ \\
\hline$\alpha$-Galactosidase & + & $3 / 13$ \\
$\beta$-Galactosidase & + & $0 / 13$ \\
Glycerol & + & $1 / 13$ \\
Hippurate hydrolysis & $\mathrm{V}$ & $0 / 13$ \\
Leucine arylamidase & + & $4 / 13$ \\
D-Melibiose & + & $0 / 13$ \\
Pyrrolidonyl arylamidase & + & $1 / 13$ \\
Raffinose & + & $0 / 13$ \\
\hline
\end{tabular}

\section{Description of Enterococcus canintestini sp. nov.}

Enterococcus canintestini (can.in.tes'ti.ni. L. gen. n. canis of a dog; L. neut. n. intestinum gut; N.L. gen. n. canintestini of the gut of a dog).

Cells are non-motile, small, Gram-positive cocci. They are predominantly arranged in small groups. On Columbia sheep blood agar, colonies are circular, non-pigmented, smooth, shiny and milky, with diameters up to $3 \mathrm{~mm}$. Strains show homogeneous growth in brain-heart infusion broth (Oxoid). Growth is not enhanced by the addition of $5 \% \mathrm{CO}_{2}$. Growth is slow at $25^{\circ} \mathrm{C}$, better at $30^{\circ} \mathrm{C}$ and optimal at $37^{\circ} \mathrm{C}$; growth at $42^{\circ} \mathrm{C}$ is equal to or slower than at $37^{\circ} \mathrm{C}$. Strains grow in $6.5 \% \mathrm{NaCl}$ broth. On Edward's Streptococcus selective medium, aesculin-degrading colonies are formed. Blackening occurs on aesculin bile agar. Strains grow and tetrazolium chloride is reduced on Slanetz \& Bartley agar. The strains do not react with Lancefield groups A, B, C, D, G or F antisera. Negative reactions in API tests for hippurate, $\beta$-galactosidase, $\beta$-glucuronidase and alkaline phosphatase. All strains are positive for arginine, aesculin and the Voges-Proskauer test. Few strains are positive in tests for leucine arylamidase, pyrrolidonyl arylamidase or $\alpha$-galactosidase $(4 / 13,1 / 13$ and $3 / 13$ positive, respectively). Acid is produced in the API 20 STREP and/or API $50 \mathrm{CH}$ kits in tests with ribose, D-galactose, D-glucose, D-fructose, D-mannose, methyl $\alpha$-D-glucopyranoside, $N$ acetylglucosamine, amygdalin (sometimes weak), arbutin, salicin, D-cellobiose, D-maltose, D-sucrose, trehalose, gentiobiose and D-tagatose. Most strains react positively in tests with D-turanose (11/13 positive with two weak reactions), 2ketogluconate (8/13 strains with often weak reactions) and lactose (12/13 positive in API $50 \mathrm{CH}$ and $10 / 13$ positive in API 20 STREP). Few strains produce acid from methyl $\alpha$-Dmannopyranoside (2/13 strains) and only one of 13 strains 
produces acid from glycerol. Reactions are also straindependent for acid production from D-lyxose (5/13 positive, 7/13 negative and one weak reaction). No acid is produced from erythritol, D- or L-arabinose, D- or L-xylose, D-adonitol, methyl $\beta$-D-xylopyranoside, L-sorbose, Lrhamnose, dulcitol, inositol, mannitol, sorbitol, Dmelibiose, inulin, D-melezitose, raffinose, starch, glycogen, xylitol, D- or L-fucose, D- or L-arabitol, gluconate or 5ketogluconate. DNA G $+\mathrm{C}$ content is $36-37 \mathrm{~mol} \%$.

The type strain, LMG $13590^{\mathrm{T}}\left(=\mathrm{CCM} 7285^{\mathrm{T}}\right)$, was isolated from dog faeces.

\section{Acknowledgements}

S.M.N. acknowledges a PhD scholarship from the Ministry of Education and Higher Education. J.S. acknowledges grants from the Fund for Scientific Research (FWO), Belgium. We thank Katrien Vandemeulebroecke for her technical assistance.

\section{References}

Baele, M., Baele, P., Vaneechoutte, M., Storms, V., Butaye, P., Devriese, L. A., Verschraegen, G., Gillis, M. \& Haesebrouck, F. (2000). Application of tRNA intergenic spacer PCR for identification of Enterococcus species. J Clin Microbiol 38, 4201-4207.

Collins, M. D., Rodrigues, U. M., Pigott, N. E. \& Facklam, R. R. (1991). Enterococcus dispar sp. nov. a new Enterococcus species from human sources. Lett Appl Microbiol 12, 95-98.

De Graef, E. M., Devriese, L. A., Baele, M., Vancanneyt, M., Swings, J., Haesebrouck, F. \& Decostere, A. (2005). Identification of enterococcal, streptococcal and Weissella species in the faecal flora of individually owned dogs. J Appl Microbiol 99, 348-353.

Devriese, L. A., Collins, M. D. \& Wirth, R. (1992). The genus Enterococcus. In The Prokaryotes: A Handbook on the Biology of Bacteria: Ecophysiology, Isolation, Identification, Applications, 2nd edn, pp. 1465-1481. Edited by A. Balows, H. G. Trüper, M. Dworkin, W. Harder \& K. H. Schleifer. New York: Springer.

Devriese, L. A., Pot, B., Van Damme, P., Kersters, K. \& Haesebrouck, F. (1995). Identification of Enterococcus species isolated from foods of animal origin. Int J Food Microbiol 26, 187-197.

Ezaki, T., Hashimoto, Y. \& Yabuuchi, E. (1989). Fluorometric deoxyribonucleic acid-deoxyribonucleic acid hybridization in microdilution wells as an alternative to membrane filter hybridization in which radioisotopes are used to determine genetic relatedness among bacterial strains. Int J Syst Bacteriol 39, 224-229.

Franz, C. M. A. D., Holzapfel, W. H. \& Stiles, M. E. (1999). Enterococci at the crossroads of food safety? Int J Food Microbiol 47, $1-24$.
Goris, J., Suzuki, K., De Vos, P., Nakase, T. \& Kersters, K. (1998). Evaluation of a microplate DNA-DNA hybridization method compared with the initial renaturation method. Can J Microbiol 44, 1148-1153.

Klein, G. (2003). Taxonomy, ecology and antibiotic resistance of enterococci from food and the gastro-intestinal tract. Int $J$ Food Microbiol 88, 23-31.

Marmur, J. (1961). A procedure for the isolation of deoxyribonucleic acid from microorganisms. J Mol Biol 3, 208-218.

Mesbah, M., Premachandran, U. \& Whitman, W. B. (1989). Precise measurement of the $\mathrm{G}+\mathrm{C}$ content of deoxyribonucleic acid by high-performance liquid chromatography. Int J Syst Bacteriol 39, 159-167.

Naser, S., Thompson, F. L., Hoste, B., Gevers, D., Vandemeulebroecke, K., Cleenwerck, I., Thompson, C. C., Vancanneyt, M. \& Swings, J. (2005a). Phylogeny and identification of Enterococci by atpA gene sequence analysis. J Clin Microbiol 43, 2224-2230.

Naser, S. M., Thompson, F. L., Hoste, B., Gevers, D., Dawyndt, P., Vancanneyt, M. \& Swings, J. (2005b). Application of multilocus sequence analysis (MLSA) for rapid identification of Enterococcus species based on rpoA and pheS genes. Microbiology 151, 2141-2150.

Niemann, S., Puehler, A., Tichy, H. V., Simon, R. \& Selbitschka, W. (1997). Evaluation of the resolving power of three different DNA fingerprinting methods to discriminate among isolates of a natural Rhizobium meliloti population. J Appl Microbiol 82, 477-484.

Pot, B., Vandamme, P. \& Kersters, K. (1994). Analysis of electrophoretic whole-organism protein fingerprints. In Chemical Methods in Prokaryotic Systematics. Edited by M. Goodfellow \& A. G. O’Donnell, pp. 493-521. Chichester: Wiley.

Stackebrandt, E., Frederiksen, W., Garrity, G. M. \& 10 other authors (2002). Report of the ad hoc committee for the re-evaluation of the species definition in bacteriology. Int J Syst Evol Microbiol 52, 1043-1047.

Švec, P., Devriese, L. A., Sedláček, I., Baele, M., Vancanneyt, M., Haesebrouck, F., Swings, J. \& Doškař, J. (2001). Enterococcus haemoperoxidus sp. nov. and Enterococcus moraviensis sp. nov., isolated from water. Int J Syst Evol Microbiol 51, 1567-1574.

Vancanneyt, M., Mengaud, J., Cleenwerck, I., Hoste, B., Dawyndt, P., Degivry, M. C., Ringuet, D., Janssens, D. \& Swings, J. (2004). Reclassification of Lactobacillus kefirgranum Takizawa et al. 1994 as Lactobacillus kefiranofaciens subsp. kefirgranum subsp. nov., and emended description of L. kefiranofaciens Fujisawa et al. 1988. Int J Syst Evol Microbiol 54, 551-556.

Welsh, J. \& McClelland, M. (1991). Genomic fingerprints produced by PCR with consensus tRNA gene primers. Nucleic Acids Res 19, 861-866.

Zeigler, D. R. (2003). Gene sequences useful for predicting relatedness of whole genomes in bacteria. Int J Syst Evol Microbiol 53, 1893-1900. 